Research Papers in Environmental and Spatial Analysis No.105

\title{
Agglomeration economies and the location of Foreign Direct Investment: quasi-experimental evidence from Romania
}

Christian A. L. Hilber* and Ioan Voicu ${ }^{* *}$

March 2006

ISBN 0753018349

We thank Vicki Been, Gilles Duranton, Hiranya Nath, Alexandru Voicu, and seminar participants at the $51^{\text {st }}$ Annual North American Meetings of the Regional Science Association International for helpful comments. Any errors, of course, are our own.

* London School of Economics, Department of Geography and Environment, Houghton Street, London WC2A 2AE, United Kingdom, c.hilber@1se.ac.uk.

** New York University, School of Law, Furman Center for Real Estate and Urban Policy, 110 West $3^{\text {rd }}$ St, New York, NY 10012, United States, voicui@juris.law.nyu.edu. 


\begin{abstract}
How important are agglomeration economies for the location of foreign manufacturing plants? We investigate this question by combining innovations from previous studies and by taking advantage of a quasi-experimental setting: the political and economic transition in Romania. The recent, sudden and sustained influx of foreign investors into Romania provides an ideal setting to disentangle agglomeration economies from endowment effects. Using a countylevel conditional logit set-up that controls for choice-specific fixed effects and endowment effects, we find that external economies from industry-specific foreign agglomeration and service agglomeration are important location determinants. Increases in the number of foreign plants and in service employment density by 10 percent make the average county 2.2 and 6.2 percent more likely to attract a new foreign investor. Local labor market conditions also matter. Our findings suggest that results are sensitive to the choice of geographical unit of observation and the inclusion of locational fixed effects.
\end{abstract}

JEL classification: P33, R3.

Keywords: Agglomeration economies, foreign direct investment, transition economies. 


\section{Introduction}

The role of agglomeration economies for the location choice of firms and economic growth is one of the most vital questions in urban and international economics. Various theoretical concepts suggest that clustering of economic activities in one form or the other results in cost savings and productivity gains for firms, thereby influencing their location decisions.

More recently, researchers have started to direct their focus on foreign firms and to investigate the role of agglomeration economies for the location of foreign direct investment (FDI) using discrete choice models (e.g., Head, Ries, and Swenson 1995; Guimarães, Figueiredo, and Woodward 2000). ${ }^{1}$ Our study—which investigates the location decision of foreign manufacturing plants within Romania—builds on this literature and advances it in three important ways.

First, the political and economic transition process in Romania provides an excellent setting to study the location choice of FDI. The sudden opening of the country to FDI after the overthrown of the communist regime in 1989 provides a quasi-experimental setting in that the political change led to a large influx of foreign capital over a short period of time. As a result of the recent nature of the FDI inflow into Romania, foreign-industry specific clusters originated under very different conditions than domestic industry-specific ones. For example, real transportation costs of endowments were very important 100 or 150 years ago, at a time when many domestic industries developed, but were less relevant in the 1990s. We exploit this fact in our empirical strategy for separating agglomeration and endowment effects.

Second, we simultaneously address many drawbacks identified in previous research. In particular, we consider only greenfield plants and use a geographical unit of observation-a Romanian county ${ }^{2}$ - that coincides well with Marshall's notion of agglomeration. At the same time, we use a conditional logit model that controls for unobserved location characteristics by including choice specific (county-level) fixed effects; and, we address the issue of separating endowment effects from agglomeration economies. To our knowledge, none of the previous studies has simultaneously addressed all these issues.

\footnotetext{
1 The standard discrete choice model used to analyze the location decision of foreign firms is McFadden's (1974) conditional logit model (CLM). The model has many significant advantages over alternative models; in particular, it has a clear microeconomic justification (see Section 3 for a detailed discussion of the approach).

2 The Romanian counties have an average area of 5,792 $\mathrm{km}^{2}$ and an average population of 544,637.
} 
Third, the location of FDI in transition economies — such as Romania-is a seriously understudied research area. ${ }^{3}$ Transition economies differ from developed countries, for example, in that labor market characteristics may be relatively more important for investors' location choices. Transition economies, with their low labor costs and a large supply of skilled manufacturing workers, are likely to attract foreign firms with labor-intensive production processes. Since labor market conditions are critical for the performance of labor-intensive firms, we would expect these conditions to be relatively more important determinants of FDI location in transition economies than in, say, developed countries, which may have other comparative advantages. Thus, our study may provide very useful guidance for the design of effective regional policies aimed at attracting FDI to transition economies.

In this context, Romania provides an ideal empirical setting for a number of reasons above and beyond the fact that the country's transition process can be interpreted as a quasi-experiment. For example, Romania holds a top position in Eastern Europe in terms of the number of foreign start-ups established since the beginning of the 1990's. Almost 50,000 establishments with foreign participation were set up in Romania between 1990 and 1996 alone (Voicu 2000). ${ }^{4}$ This number includes 1540 foreign-owned greenfield plants in the manufacturing sector - the sample used in our empirical analysis. In addition, the availability of detailed data for individual plant establishments and small localities in Romania (of course coupled with the use of fixed-effects) allows us to obtain more precise estimates of the impact of different types of agglomeration economies on location decisions than has previously been possible.

The main findings of our study are that industry-specific foreign agglomeration economies as well as service agglomeration economies play an important role in the location choice of foreign manufacturing plants. The effects are fairly meaningful economically. A 10 percent increase in the number of foreign plants in a county increases the probability that a foreign investor chooses the county by 2.2 percent. A 10 percent increase in service employment density makes the average county 6.2 percent more likely to attract a new foreign investor. We also confirm that the influence of local labor market conditions is quite strong in Romania, perhaps stronger than in more developed countries.

\footnotetext{
This is mainly due to data limitations in most Central and Eastern European countries.

This number includes establishments with foreign participation of all types (including joint ventures), in all economic sectors (not only manufacturing), and regardless of the amount of invested foreign capital.
} 
Our paper is organized as follows. Section 2 summarizes the related theoretical and empirical literature and describes its various contributions and shortcomings. Section 3 presents the conditional logit set-up in more detail. In Section 4, we describe the data and discuss the variables that are expected to explain the location of FDI. Section 5 then presents the empirical results. Section 6 provides concluding remarks.

\section{Background}

Understanding the location of foreign direct investment (FDI) is of importance for two main reasons. First, it is often asserted that FDI benefits domestic firms, particularly in developing or transition economies, and increases the welfare of the citizens by accelerating economic growth in the host country. ${ }^{5}$ To the extent this is true; FDI distribution within national borders may play an important role in influencing regional economic disparities. Thus, identifying the subnational determinants of the FDI distribution represents an important step towards the design of regional policies that can effectively address regional inequalities. ${ }^{6}$ Second, the location decisions of foreign firms may differ significantly from their domestic counterparts, and, consequently, the location determinants or their effects may differ between foreign and domestic investors and need to be investigated separately. For example, uncertainty with regard to locational quality and subsequent information and search costs are much higher for foreign compared to domestic investors (Caves 1996). Since an existing concentration of foreign firms facilitates the gathering of information on the local environment, either via business relationships or because it demonstrates the location's potential, economies from foreign agglomeration may be very important for international investors but less so for domestic investors (e.g., Mariotti and Piscitello (1995), and Guimarães, Figueiredo, and Woodward 2000). More generally, a number of studies have found that foreign companies value various location factors different than domestic firms (e.g., Glickman and Woodward 1988 and 1989).

5 See de Mello (1997 and 1999) for a comprehensive survey on the relationship between FDI and growth and Aitken and Harrison (1999) for a critical assessment of the claim. The empirical research on the FDI-growth relationship in transition and developing countries suggests overall that FDI has a positive impact on economic growth (e.g., Borensztein, de Gregorio, and Lee 1998, Balasubramanyam, Salisu, and Sapsford 1999, and Voicu 2000).

6 Of course, regional disparities cannot be addressed solely by attracting FDI; rather FDI should accompany domestic efforts. However, these issues are beyond the scope of this paper. 
The literature on the role of agglomeration economies for location decisions is very broad and spans three major fields in economics; urban economics, (new) economic geography, and international economics. ${ }^{7}$

On the theoretical side, the concept of agglomeration economies was first introduced by Marshall at the end of the 1890's, as a mechanism that could explain the spatial concentration of particular industries, or, in short, localization. According to Marshall (1898), agglomeration is likely to generate economies that are external to a firm but internal to a small geographic area - a “locality”. In Marshall's view, such external economies can arise from specialized labor market pooling or input sharing, as well as from technological or knowledge spillovers. Subsequent research (e.g., Goldstein and Gronberg 1984, David and Rosenbloom 1990, Helsley and Strange 1990, and Glaeser 1999) has constructed formal models to analyze and extend Marshall's concept. ${ }^{8}$ Rivera-Batiz (1988) offers a sound theoretical foundation for the understanding of external economies from urban service agglomeration. More recently, theories of the "new economic geography" emphasize the role of agglomeration economies in explaining economic growth (e.g. Krugman 1991a and 1991b, Porter 1996).

On the empirical side, numerous studies show that localization economies-positive externalities arising from spatial concentration of activity within industries—are crucial for enhancing firm productivity (e.g., Sveikauskas 1975, Henderson 1986, or Ciccone and Hall 1996). Urbanization economies - external economies stemming from the city size itself_also impact productivity, although, the results of most studies suggest that the effects may be relatively less important compared to localization economies (see Glaeser et al. 1992 and Henderson, Kuncoro, and Turner (1995) for estimates of urbanization economies). Ellison and Glaeser (1997) further demonstrate that the level of agglomeration varies considerably across industries, as does the likelihood of an industry to co-agglomerate with other industries. Finally, Jaffe, Trajtenberg, and Henderson (1993) investigate knowledge spillovers in the location of patent citation and find that knowledge spillovers are highly spatially concentrated.

More relevant to the focus of this paper, a number of empirical studies use discrete choice models to investigate the role of agglomeration economies and other factors for the location of FDI. These studies usually focus on developed countries—-mostly on the United States—and find

7 See Rosenthal and Strange (2001) for a further exposition of this topic. 
that agglomeration economies are important location determinants. However, they generally suffer from one or more of a series of drawbacks that raise questions about the accuracy of their estimates of agglomeration effects.

In much of the earlier research, agglomeration measures are crude; for example Coughlin, Terza, and Arromdee (1991), Woodward (1992), and Wheeler and Mody (1992) use total manufacturing employment as a proxy for agglomeration economies that should be at least in part industry-specific.

Almost all studies stretch the Marshallian concept of agglomeration by using a geographical unit of observation-e.g., the U.S. state, region, or even country-which is too large (e.g., Carlton 1983, Luger and Shetty 1985, Coughlin, Terza, and Arromdee 1991, Wheeler and Mody 1992, Head, Ries, and Swenson 1995, Cieslik and Ryan 2004). While large regions may be particularly inappropriate for a study of agglomeration economies, they may also be inadequate in accounting for labor market conditions and other factors that may, too, apply at the local level. ${ }^{9}$

With the notable exception of Head, Ries, and Swenson (1995), none of the prior studies includes choice-specific fixed effects in their regressions, thereby potentially failing to control for unobservable location characteristics which may cause omitted variable biases. And, with the exceptions of Head, Ries, and Swenson (1995 and 1999), past studies do not adequately distinguish between industry-level agglomeration economies and endowment effects, which may result in biased estimates of the impacts of agglomeration economies. Endowment effects represent an alternative mechanism through which localization can arise. Specifically, traditional trade theory would suggest that firms in a given industry will cluster in regions with favorable factor endowments for that industry. However, firm-specific cost savings associated with choosing an endowment-rich location diminish with the number of firms; as firms congregate, the location becomes less appealing since competition for a scarce input among users bids up the price of the input (Head, Ries, and Swenson 1995).

Finally, some studies (e.g., Coughlin, Terza, and Arromdee 1991, Mariotti and Piscitello 1995) mix greenfield investment with other types of FDI such as joint ventures, mergers and

\footnotetext{
See Quigley (1998) for a survey of the theoretical literature on the micro-foundations of agglomeration economies.

9 Woodward (1992) and Guimarães, Figueiredo, and Woodward (2000) are among the very few studies which address this question.
} 
acquisitions. However, firms have much more discretion regarding the location of new plants (greenfield investments) than with other types of investment.

There has been little empirical research on FDI location within European countries and even less within the transition countries of Central and Eastern Europe. Among the few European studies, Guimarães, Figueiredo, and Woodward (2000) focus on the location decisions of foreignowned manufacturing plants in the urban areas and outlying regions of Portugal and conclude that agglomeration economies, especially urban service agglomeration economies, are decisive location factors. Mariotti and Piscitello (1995) argue that spatial distribution of FDI is mainly governed by information costs and provide empirical evidence for Italy supporting this hypothesis. To our knowledge, there exists only one FDI location study - in addition to oursthat focuses on a transition economy in Europe. Cieslik and Ryan (2004) investigate the location determinants of Japanese companies within Poland, with a focus on the effects of Special Economic Zones.

\section{Methodology}

We model the location decision of foreign manufacturing plants using a conditional logit set up where the dependent variable is the county chosen by each investor. Following McFadden (1974), we assume that at time $t$, investor $i$ selects the county $j$ that would yield the highest profit. The conditional logit model stipulates that the profit can be decomposed into the sum of a measured term, $M_{i j t}$, and an unmeasured term, $\varepsilon_{i j t}$. If $\varepsilon_{i j t}$ is distributed independently and according to a Weibull distribution, the probability that any particular county is chosen out of the choice set of size $K$ is

$$
\operatorname{Prob}_{i j t}=\frac{e^{M_{i j t}}}{\sum_{k=1}^{K} e^{M_{i k t}}}
$$

Previous theoretical work summarized above implies that $M_{i j t}$ is influenced by a set of location characteristics. Consequently, we can estimate the effect that these characteristics have on location choice. The empirical specification can be formulated as follows: 


$$
M_{i j t}=\sum_{l=1}^{L} \beta_{l} X_{i j t}^{l}+\sum_{k=1}^{K} \gamma_{k} D_{k}
$$

where $X_{i j t}^{l}$ denotes the $l^{\text {th }}$ location specific independent variable. Relevant factors for the site selection decision usually include (but are not limited to) agglomeration effects, prices of inputs (land, labor, and capital), market demand, and quality of infrastructure. In the data section below we describe in detail the set of explanatory variables which we use in the subsequent empirical analysis.

Since it is unlikely that the variables we use adequately capture all location characteristics which influence profits, our specification also includes a set of county-specific dummy variables, $D_{k}$, to control for any unobserved time-invariant county features that may affect location decisions. The inclusion of county-specific fixed effects alleviates omitted variable biases in the coefficient estimates of the included regressors, and represents an important innovation compared to most of the previous literature. ${ }^{10}$ Moreover, these choice-specific effects also control for the existence of unobservable correlation across choices, thus alleviating concerns that the Independence of Irrelevant Alternatives (IIA) assumption of the conditional logit model (i.e., identical and independent error terms) may be violated. ${ }^{11}$

Endowment-driven localization suggests that industry-specific agglomeration variables may be correlated with unobserved industry-state specific factor conditions which are not captured by the county fixed-effects and thus are part of the error term, $\varepsilon_{i j t}$ (see Head, Ries, and Swenson (1995) for a more detailed discussion of this possibility). As a result, the agglomeration coefficient will incorporate both agglomeration economies and endowment effects. To separate the two types of effects, we essentially follow the approach suggested by Head, Ries, and Swenson (1995). Specifically, we include in our specification two industry-specific agglomeration variables - the count of foreign firms and the count of domestic firms in the same industry as the investor.

In this context it is important to note that in Romania industry-specific clusters of domestic and foreign firms differ from each other in that industry-specific clusters of foreign firms are a

10 As previously mentioned, to our knowledge, Head, Ries, and Swenson (1995) is the only other paper which controls for choice-specific fixed effects (that is, for US state fixed effects). 
very recent phenomenon (post-1989), while most domestic clusters originated a long time ago. In fact, many domestic manufacturing clusters originally developed during the $19^{\text {th }}$ and $20^{\text {th }}$ century, at a time when proximity to resource rich locations was very important (as, at that time, transportation costs were an important cost factor in production) and, therefore, arguably, firms of a particular industry clustered in locations that provided the relevant resources. ${ }^{12}$ The geographical distribution of the domestic establishments in a particular industry should therefore incorporate all the relevant information on the abundance of endowments and the intensity of resource-use in that industry. Consequently, a significant and positive coefficient on the foreign agglomeration variable, after controlling for the domestic pattern, should provide strong evidence for the existence of agglomeration economies.

To judge the contribution that our choice of geographical unit of observation, the county, brings to the estimation of agglomeration effects and other factors that apply at the local level, we also estimate a conditional logit model where the choice is among regions rather than among counties. A Romanian region is a more aggregated territorial unit which encompasses several counties. $^{13}$

\section{Data and Variables}

\subsection{Data}

To estimate the model outlined above, we obtained unique data from three Romanian sources. First, the "Statistical Abstract of Romania" (which is also the basis for the World Bank's and OECD's statistics and reports on Romania) provides detailed information on many of the county-level characteristics that are expected to play a role in the firms' location decisions (e.g., employment and average net monthly earnings by economic sector, unemployment rate, number of labor conflicts, school population of various levels of education, railway lines in operation, public roads, land area, and population density).

11 Train (1985) shows that the inclusion of choice-specific effects allows for the use of a conditional logit model in the presence of some forms of IIA violation. In particular, our empirical specification is valid as long as foreign investors have uniform perceptions of the substitutability between counties.

12 Rhode and Strumpf (2003) provide evidence for the United States that the real transportation costs have fallen substantially since the late $19^{\text {th }}$ century. Assuming that this empirical evidence broadly applies to Romania as well, one might expect that resource-endowment should have a smaller impact on firms' location choices nowadays. In particular, since the FDI influx into Romania occurred only after 1989 one might expect that local differences in endowments may be less relevant for the development of industry-specific foreign clusters. 
Second, we obtained data from the Romanian Development Agency (RDA). The RDA registers each and every establishment with foreign participation, which opened in Romania. ${ }^{14}$ Thus, the RDA maintains the most complete and reliable list of establishments with foreign participation for Romania. Specifically, the RDA provided us with information on the date of establishment, county of location, partners, amount of foreign and total capital invested, and relevant industry for all foreign manufacturing subsidiaries with at least $\$ 10,000$ in foreign capital which were established in Romania between 1990 and 1997. ${ }^{15}$ In order to ensure that the sample of foreign plants used in the analysis includes only greenfields, we eliminated all establishments in which the Romanian partner was a juridical person (i.e., a firm). ${ }^{16}$

Finally, we supplemented our data with plant-level information from the Chamber of Commerce and Industry of Romania, including the county of location and two-digit industry code for all domestic manufacturing plants with at least 20 employees for 1994 and 1996.

Table 1 shows the spatial distribution of the 1540 foreign-owned greenfield plants in our sample. ${ }^{17}$ Notice that the overwhelming majority of these investments (61.2 percent) are concentrated in the capital city, Bucharest. Other more popular locations include several counties in Transylvania (Arad, Bihor, Brasov, Cluj, Sibiu, and Harghita), one on the Western border (Timis) and one on the Black Sea Coast (Constanta).

Table 2 describes the FDI temporal trends for our study period, 1990-1997. Post World War II, Romania was among the first East-European countries to (re-)open the door to FDI. In 1972, a law was passed that allowed the establishment of international joint ventures with no more than 49 percent of foreign ownership. However, the effective outcome of this policy was very meager at that time for reasons such as Western companies' natural suspicion of communist governments and fears of new changes of the political situation, bad regulations, bureaucratic inefficiency, etc.

13 Romanian regions are a concept newly defined by the Ministry of Development and Prognosis to ensure a more efficient implementation of its regional development policies.

14 The RDA was established in 1991, as a specialized body aiming at supporting the economic reform by attracting foreign direct investment. In 1996, the RDA became a founding member of the World Association of Investment Promotion Agencies, an international organization created at the initiative of UNCTAD with support from OECD, World Bank and World Trade Organization (see Romanian Development Agency (1996) for more details about the role and accomplishments of the RDA).

15 Industries recorded by RDA are either at the two-digit level or are aggregations of several two-digit industries.

16 RDA staff indicated that while many of the establishments with a firm as domestic partner are greenfields, some may represent joint ventures or acquisitions.

17 In the regression models, the number of observations (choosers) is slightly smaller (1519) since we exclude the plants set up in 1990. However, the plants established in 1990 are used in the calculation of the foreign agglomeration variable for all subsequent set ups. 
Therefore, it is reasonable to assume that our study period-which starts with year one after the overthrown of the communist regime-captures the very beginning of FDI in Romania. ${ }^{18}$

Several things are apparent in Table 2. First, the FDI activity had a slow start following the events that led to the overthrown of the communist regime in 1989; only 21 foreign-owned greenfield plants were established in 1990, and less than 100 were set up in each of the following three years. The foreign investors' initial reluctance to invest in Romania can be attributed, at least in part, to the country's political and economic instability during that period, as well as to a very slow start of the economic reforms. Second, starting in 1994 and continuing over the next couple of years, there was a strong surge in the number of foreign start-ups; for example, in 1994, 360 new greenfield establishments were established—over four times more than in the previous year. This sharp increase was likely driven by the beginning of macroeconomic stabilization in $1994 .{ }^{19}$ Finally, in 1997, there was a significant drop in the number of new foreign establishments. While we can only speculate about the causes of this decline, it is likely that factors such as the beginning of a recession, the slower-than-expected pace of economic reform, and the foreigners' increased realization of the widespread corruption at all levels of the Romanian society played and important role.

The distribution of FDI by industry is presented in Table 3 and shows priority towards food (40.0 percent) and light industry (24.6 percent), which includes textile, clothing, leather, and shoes. These are industries with a long tradition in Romania. They are also labor intensive, which likely captured the attention of foreign investors through a promise of cheap but skilled labor force.

\subsection{Explanatory Variables}

As shown in the previous section, the probability that a foreign firm selects a particular county depends on the levels of the county's characteristics that influence profits relative to the levels of these characteristics in other counties. These local characteristics can be categorized as affecting firms' revenues or costs. Table 4 defines and summarizes the location (county-specific) factors which are used as explanatory variables in the conditional logit model.

18 Prior to the onset of communism in 1945, there was a significant number of foreign firms doing business in Romania; however, they were all taken over by the state as a result of the communists' nationalization policy. 


\section{Agglomeration Variables}

The focal variables of our model are various measures that capture different types of agglomeration economies. Here we follow Head, Ries, and Swenson (1995) who argue that the impact of agglomeration economies on location decisions can be better captured by accounting for different types of agglomeration. Specifically, we include four variables to capture agglomeration economies. Our first measure is the log of the number of plants with foreign participation in the same industry as the investor. This variable captures industry-specific foreign agglomeration economies, a form of localization economies. Foreign firms may be attracted to counties with existing concentrations of foreign-owned firms in the same industry due to technological or pecuniary externalities. As mentioned at the outset, pecuniary externalities from foreign agglomeration may include not only economies from specialized labor-pooling and the existence of intermediate suppliers but also substantial reductions in the information and search costs associated with foreign investors' high uncertainty about the local environment.

Our second agglomeration measure is the log of the number of domestic plants in the same industry as the investor. This variable captures industry-specific domestic agglomeration economies (another form of localization economies), but also endowment effects. ${ }^{20}$ As mentioned in the methodology section, the main role of this variable is to control for endowment effects, thus allowing us to obtain a more accurate estimate of industry-specific foreign agglomeration economies. Given the availability of data on the number of domestic plants for two years, 1994 and 1996, foreign investments that started between 1991 and 1994 are matched to 1994 domestic counts; and later foreign investments are matched to 1996 domestic counts. ${ }^{21}$

Our third measure is the log of total employment in the tertiary sector (business and financial services) per square kilometer. This variable captures service agglomeration economies. As Woodward (1992) argues, urban service agglomeration economies may be particularly relevant to

19 In 1994, GDP increased by 3.4 percent relative to 1993 , exports increased by $22.6 \%$, imports decreased by $5.5 \%$, personal savings doubled, inflation dropped to $61.7 \%$ (from $295.5 \%$ in 1993), and the private sector share in GDP reached 35\% (Voicu 2000).

20 Localization economies from domestic agglomeration usually result from technology spillovers, the existence of intermediate suppliers, and labor-pooling.

21 Given that the pace of economic restructuring reforms was slow in Romania for much of the 1990s, there was fairly little variation in the number of domestic manufacturing enterprises, especially during the first half of the decade. Therefore, the two years for which the domestic plant counts are available should be enough to adequately capture domestic agglomeration economies over the whole study period. 
foreign firm location decisions. This is because foreign firms often prefer the availability of local professional services. $^{22}$

Finally, our fourth focal variable is the log of total manufacturing employment per square kilometer. This measure of total manufacturing activity is included to account for other types of agglomeration effects that are not captured by the other three measures. For example, the variable captures economies arising from input linkages among firms of different manufacturing industries. It may also capture knowledge spillovers from outside the core industry but within the manufacturing sector, that is, economies arising from cross-fertilization across manufacturing industries. ${ }^{23}$ Empirical evidence from Henderson, Kuncoro, and Turner (1995) suggests that these positive technological externalities from cross-fertilization are only relevant for new high-tech industries, while economies arising from industry-specific agglomeration are also relevant for mature capital goods industries. Given that our empirical analysis considers location decisions of firms competing in mature industries, one might expect that, controlling for industry-specific agglomeration, the manufacturing agglomeration variable may have little or no (positive) impact on the location decisions of foreign investors. Nevertheless we include this measure as a potential control variable.

\section{Other Location Factors}

Our empirical model includes a number of additional factors that are expected to affect the location decisions of foreign firms. On the cost side of the profit function, labor market conditions quickly come to mind - they affect the prices of local inputs including labor itself, as well as any locally supplied intermediate goods. Wages, the labor-management environment, and the availability of labor are important labor market characteristics - and those which are usually employed in location studies. When measuring wage costs, one needs to account for unit labor costs since workers differ in skills and level of qualification (Woodward 1992). To address this issue, we include in our specification the average manufacturing monthly real wage (in log

22 See Rivera-Batiz (1988) for a theoretical foundation of this argument.

23 Economies may arise from cross-fertilization of ideas in diversified manufacturing locations. Jacobs (1969) first described the idea of economies arising from knowledge spillovers from outside the core industry. Following Jacob's logic, large diversified cities should be more attractive to firms than less diversified locations. While 'Jacob externalities' describe positive technological spillovers across firms of all industries, the manufacturing agglomeration variable only captures positive externalities across firms of industries within the manufacturing sector. In this context it should be noted that the variable is only a rough measure for economies arising from diversification among manufacturing industries as it does not directly measure the degree of such diversification. 
terms), as well as the log of numbers of high-schools and vocational/apprentice schools per total manufacturing employment as proxies for the educational and skill levels of the local workforce. Higher wages are expected to deter FDI. However, the empirical evidence on the impact of labor costs is mixed. For example, Bartik (1985), Luger and Shetty (1985), Coughlin, Terza, and Arromdee (1991) found that higher wages make a location less attractive to foreign investors; on the other hand, Glickman and Woodward (1987), Ondrich and Wasylenko (1993), and Guimarães, Figueiredo, and Woodward (2000) did not find a statistically significant relationship. We expect the two measures of educational and skill levels to be positively related to the probability of locating a new plant in a county - a usual finding in the location literature (see, for example, Glickman and Woodward (1987) and Coughlin and Segev 2000).

The extent of unionized labor is the most widely used indicator of the labor-management environment. Since we lack unionization data, we employ the number of labor conflicts (computed per total manufacturing employment and expressed in log terms), which is largely believed to be closely associated with the union strength. Coughlin, Terza, and Arromdee (1991) and Coughlin and Segev (2000) notice that in regions with low unionization rates the degree of unionization is often touted by officials seeking to promote economic development. The argument is that such an environment allows foreign firms to introduce new managerial practices and, more generally, to pursue profit maximization unhindered by union contract restrictions. This view has found empirical support in some studies (e.g., Bartik 1985); however, other more recent studies found that the unionization rate doesn't matter (Head, Ries, and Swenson 1995; Coughlin and Segev 2000) or that higher rates are conducive to FDI (Coughlin, Terza, and Arromdee 1991). Nonetheless, as a working hypothesis we expect a large number of labor conflicts to be a deterrent for FDI location. ${ }^{24}$

The last labor market characteristic that we explore is the unemployment rate (in log terms). This factor has an ambiguous effect on the location choice. A high unemployment rate may be conducive to FDI if it indicates labor availability. Findings by Head, Ries, and Swenson (1995) and Coughlin, Terza, and Arromdee (1991), among others, are consistent with this hypothesis. However, higher unemployment can also signal less competitive conditions and a lower quality

24 This hypothesis may be particularly true for Romania, where, as mentioned above, FDI tends to be labor intensive and thus, labor market conditions are likely important location factors. 
of life that tend to discourage foreign investors (see Woodward (1992) for empirical support for this argument).

Land costs represent another potential location determinant on the cost side of the profit function. Since direct information on this factor is not available, we follow Bartik (1985) and Guimarães, Figueiredo, and Woodward (2000) and use the log of population density to proxy for industrial land costs. The argument here is that population density likely reflects land costs because residential and industrial users compete for land. We expect this factor to be negatively correlated with the county's attractiveness for foreign firms.

Capital costs, proxied by the interest rate, represent yet another cost component. However, since they are usually invariant across locations, they are generally not included as explanatory variables in location choice models. We also do not include taxes in our model because in Romania, those related to capital costs are set at the national level and thus do not vary across counties.

On the revenue side, per capita income is a usual measure of market demand. However, it is often argued in the literature that the market served by foreign firms is rarely limited to their region of location, especially if the region is small, like the counties in our study (e.g., Coughlin and Segev 2000 and Mariotti and Piscitello 1995). Therefore we chose not to include this variable either.

Infrastructure quality is often considered a factor of relevance in firms' location decisions, as well-developed infrastructure leads to higher regional productivity and may thereby increase firm profits. The empirical evidence usually supports the expectations of a positive relationship between infrastructure variables and FDI (e.g., Bartik 1985; Coughlin, Terza, and Arromdee 1991; Coughlin and Segev 2000). Infrastructure is captured in our models with two variables measuring the road and railway densities (in log terms). Note, however, that we exclude the two infrastructure quality indicators in our fixed effects models. This is because the two variables remained unchanged over our study period and therefore are perfectly collinear with the county dummy variables.

All the explanatory variables are one year lagged (with the exception of the infrastructure quality indicators which are time invariant). We believe that the use of lagged variables is justified for at least four reasons: 1) location choices are important strategic decisions which firms make, and thus require a thorough preliminary study of the local markets; 2) it takes some 
time to register and open the business once the location choice is made, given the logistic and bureaucratic hurdles associated with this process (which in a transition country like Romania may be quite significant); 3) agglomeration economies with pre-existing foreign direct investment will only start to occur with firms that have been present for some time; and 4) lagging of variables alleviates potential endogeneity bias. ${ }^{25}$

For some of the explanatory variables, data was not available for the beginning of our study period: employment in the tertiary sector (service agglomeration), manufacturing employment density (total manufacturing agglomeration) and unemployment rate were not available for 1990; number of labor conflicts was not available for 1990 and 1991; and wage was not available for 1990-1992. Given that all these factors, except wages, changed very little in the few years immediately following the communism collapse (at the end of 1989), we imputed the missing values of these variables with their values for the first available year of data. We imputed the missing wage values via extrapolation of the available years of data based on the average annual wage growth during these years.

\section{Empirical Results}

In the following, we first discuss results for our empirical specification that models the choice of foreign investors among Romanian counties. Next, we present results for a similar specification in which the location is defined by regions instead of counties.

\subsection{Estimation Results for Model with Choice among Counties}

Our main goal is to obtain consistent estimates of the agglomeration effects, and we believe that the inclusion of county fixed effects along with other (observed) location factors in the econometric model is crucial for this purpose. However, we begin by presenting estimation results for a baseline specification without county fixed effects, similar to the ones used in many previous empirical studies. Starting with such a common model, we can check whether the results for Romania differ significantly from estimates that have been found previously for other

\footnotetext{
25 A one year lag has been chosen for the following reason. Our dataset only includes seven years of data and any further increase in the time lag therefore significantly reduces the temporal variation. This is particularly problematic given that in our county fixed effects specification most coefficients are estimated based solely on the temporal variation exhibited by the explanatory variables (the only exceptions are the industry-specific foreign and domestic agglomeration coefficients which use both temporal and industry variation in their corresponding variables).
} 
countries. Additionally, estimating this typical specification enables us to assess the role that the inclusion of location-specific fixed effects plays in alleviating omitted variable biases.

Parameter estimates and elasticities ${ }^{26}$ for the baseline model (Model 1) are reported in the first two columns of Table 5. To begin with, as expected, we find that agglomeration coefficients have a positive sign and are, with one exception (total manufacturing agglomeration), statistically significant at the 1 percent level. The coefficients on the other location variables have, in general, expected signs, although only a few are statistically significant; the ones on high-schools, railway density, and unemployment rate. The negative effect of the unemployment rate on the county's attractiveness seems to suggest that higher rates are indicative of lack of competition and/or lower quality of life. But it may also be simply a result of omitted variable bias. Contrary to our expectations, labor costs and labor conflicts have both positive coefficients, albeit insignificant. Nonetheless, these findings may, too, be driven by omitted variable bias. ${ }^{27}$

Looking at the elasticity estimates in column (2), the elasticity for industry-specific foreign agglomeration is $\mathbf{0 . 5 5}$, that is, an increase in a county's number of plants with foreign participation in the same industry as the investor by 10 percent, will increase the probability that the foreign investor will choose that particular county by 5.5 percent, on average - obviously, a quantitatively very meaningful result. Similar elasticities are obtained for industry-specific domestic agglomeration (0.51) and service agglomeration (0.53). Interestingly, the FDI elasticities with respect to the two industry-specific agglomeration variables are very similar to those obtained by Head, Ries, and Swenson (1995). Among the other significant location determinants, FDI seems somewhat less responsive to the unemployment rate (elasticity=-0.24) and railroad infrastructure (elasticity $=0.33$ ) but very responsive to educational attainment (elasticity=0.99).

We turn next to our preferred model, which adds county-specific fixed effects. Coefficient estimates for this model, which are reported in column (3) of Table 5, clearly indicate that the inclusion of county fixed effects strongly affects the results. First, while the coefficient on

\footnotetext{
26 The coefficients of a conditional logit model are not directly tied to the marginal effects and, thus, their magnitude is not straightforward to interpret. One way to assess their magnitude is to calculate average probability elasticities. This computation is particularly easy to perform for a log-linear specification of the profit function, like ours (see Head, Ries, and Swenson (1995) and Coughlin, Terza, and Arromdee (1991), among others, for detailed elasticity calculations). These elasticities enable us to assess by how much each of the explanatory variables affects location choice probabilities.

27 Head, Ries, and Swenson (1995) and Coughlin and Segev (2000) find similar results for unionization rate and wage, respectively, and they, too, allude to potential biases due to omitted variables.
} 
industry-specific foreign agglomeration is still positive and highly significant, its magnitude drops to half of that from the baseline model. The coefficients on the other agglomeration variables change little.

Second, notice the dramatic changes in sign, significance, and magnitude for the coefficients on all labor market characteristics. The labor costs variable has now a coefficient which is negative and significant, as hypothesized, and much larger than the benchmark one; the unemployment rate coefficient becomes positive but is no longer significant; the effect of labor conflicts on the probability of a county being chosen for investment is now negative and significant, as expected; vocational/apprentice schools, while keeping the positive sign, become a much stronger and statistically significant location determinant; and the high-schools variable now becomes statistically insignificant (with a negative sign).

The substantial differences in estimates between our core, fixed effects specification and the baseline model underscore the great potential for omitted variable bias in models that do not include choice-specific fixed effects.

The average probability elasticities for our fixed-effects model, shown in column (4) of Table 5, indicate that if the number of foreign plants in a given industry within the average county increases by 10 percent, the probability that a subsequent investor in that industry will locate in that county increases by 2.2 percent. By comparison, the elasticity of foreign plant startups with respect to industry-specific domestic agglomeration is more than double (0.48). FDI seems also very responsive to service agglomeration. A 10 percent increase in service employment density makes the average county 6.2 percent more likely to attract a new investor.

Among the other significant location factors, labor costs and professional skill levels (as proxied by the number of vocational/apprentice schools) clearly stand out with elasticities of -1.71 and 1.52 , respectively. By comparison, the FDI elasticity with respect to labor conflicts is much smaller, -0.13 .

\subsection{A Sensitivity Test: Estimation Results for Model with Choice among Regions}

Comparing estimates from county-level and region-level models allows us to assess the importance of using appropriately small geographical units in the estimation of agglomeration effects and of the influences of other location factors. 
The last two columns of Table 5 report the results for our fixed-effects model with the region as location choice variable. To begin with, the coefficients of our two industry-specific agglomeration variables both have the anticipated positive sign and are statistically significant at the one percent level. Results are also important in quantitative terms. For example, an increase in the number of plants with foreign participation in the same industry as the investor by 10 percent increases the likelihood that a foreign investor chooses the specific region by 2.8 percent. A 10 percent increase of the number of domestic plants has an even stronger effect; it increases the probability by 3.5 percent. These elasticities are moderately different from the ones obtained in the county-level model.

However, in contrast to the corresponding county-level estimates, service agglomeration no longer seems to significantly affect the location choice of foreign investors. This result implies that while the service agglomeration in the county is very important for foreign investors' location decision, the service agglomeration in the region is irrelevant. Moreover, the total manufacturing agglomeration coefficient, while still negative, is now statistically significant (albeit only at the 10 percent level), and the corresponding elasticity is very large (-3.0), perhaps implausibly so.

None of the other location factors seem to matter in the region-level specification, again, a finding different from the county-level results.

Overall, it appears that using highly aggregated geographic units to model firm location choices has the potential to produce misleading results with respect to both agglomeration effects and the role of other location determinants.

\section{Conclusion}

This study investigates the magnitude of different types of agglomeration economies and assesses their importance for location decisions of foreign firms in Romania. Using a conditional logit model which controls for choice-specific effects and endowment effects, we find strong evidence of industry-specific foreign agglomeration effects and service agglomeration economies, and demonstrate that the effects are economically meaningful. Specifically, we find that a 10 percent increase in the number of foreign plants in a given industry within the average county results in a 2.2 percent increase in the likelihood that a subsequent foreign investor in that industry will choose that county. And, a 10 percent increase in service employment density has 
an even stronger positive effect on the location decision of FDI, it makes the average county 6.2 percent more likely to attract a new investor.

Consistent with the view that most foreign investors outsource labor-intensive production processes into Romania, we also find empirical evidence for the importance of labor market conditions in FDI location decisions. In particular, increases in labor costs and number of labor conflicts substantially diminish a county's attractiveness to foreign investors, whereas the availability of vocationally skilled labor has a significant positive effect on location choice.

Finally, all else equal, we find no evidence that the total employment in the (mature) manufacturing sector has any positive effect on a foreign firm's investment decision.

Robustness tests reveal that controlling for choice-specific fixed effects has an important impact on our estimates. For example, the elasticity for the industry-specific foreign agglomeration in the specification without fixed effects is 0.55 , while the elasticity for the model with county-level fixed effects is only 0.22 . This may suggest that previous studies that do not control for choice-specific fixed effects may overestimate the impact of localization economies. Our results are also sensitive to the choice of geographical level of observation. As one might expect intuitively, we find evidence for service specific agglomeration economies when we use a geographical unit of observation-the Romanian county-that coincides well with the Marshallian notion of agglomeration, but service specific agglomeration economies become irrelevant when using more aggregated, region-level data. Additionally, labor market conditions become insignificant in the region-level specification.

Our finding that industry-specific foreign agglomeration economies are important determinants of FDI location implies that regional policies that succeed in attracting investment will likely realize long-run benefits from increased agglomeration. Thus, from a policy point of view, our results suggest that regional policies aimed at reducing regional inequalities via FDI inflows should include offering strong incentive packages ${ }^{28}$ to attract initial investors in the manufacturing sector in the underdeveloped regions. Our findings also suggest that stimulating the services sector in these regions, and alleviating disparities in labor market conditions may be viable policy options, as well.

28 Such packages may include, for example, temporary subsidies such as tax holidays or customs duty holidays. 
Research Papers in Environmental and Spatial Analysis No.105

\section{References}

[1] Aitken, B. and A. Harrison. 1999. "Do Domestic Firms Benefit from Direct Foreign Investment? Evidence from Venezuela," American Economic Review, 89, 605-18.

[2] Balasubramanyam, V.N., M. Salisu, and D. Sapsford. 1999. "Foreign Direct Investment as an Engine of Growth," Journal of International Trade and Economic Development, 8, 27 40.

[3] Bartik, T.J. 1985. "Business Location Decisions in the United States: Estimates of the Effects of Unionization, Taxes and other Characteristics of States," Journal of Business and Economic Statistics, 3, 14-22.

[4] Borensztein, E., J. de Gregorio, and J.-W. Lee. 1998. "How Does Foreign Investment Affect Economic Growth?," Journal of International Economics, 45, 115-35.

[5] Carlton, D.W. 1983. "The Location and Employment Choices of New Firms: An Econometric Model With Discrete and Continuous Endogenous Variables," Review of Economics and Statistics 65, 440-449.

[6] Caves, E.R. 1996. Multinational Enterprise and Economic Analysis. Cambridge: Cambridge University Press.

[7] Ciccone, A. and R.E. Hall. 1996. "Productivity and the Density of Economic Activity," American Economic Review, 86, 54-70.

[8] Cieslik, A. and M. Ryan. 2004. "Location Determinants of Japanese Multinationals within Poland," Unpublished manuscript.

[9] Coughlin, C.C. and E. Segev. 2000. "Location Determinants of New Foreign-Owned Manufacturing Plants,” Journal of Regional Science, 40, 323-351.

[10] Coughlin, C., J.V. Terza, and V. Arromdee. 1991. "State Characteristics and the Location of Foreign Direct Investment within the Unites States," Review of Economics and Statistics, 73, 675-83.

[11] David, P.A. and J.L. Rosenbloom.1990. "Marshallian Factor Market Externalities and the Dynamics of Industrial Location," Journal of Urban Economics, 28, 349-370.

[12] De Mello, L. 1997. "Foreign Direct Investment in Developing Countries and Growth: A Selective Survey," Journal of Development Studies, 34, 1-34. 
[13] De Mello, L. 1999. "Foreign Direct Investment Led Growth: Evidence from Time-Series and Panel Data”, Oxford Economic Papers, 51, 133-151.

[14] Ellison, G. and E. Glaeser. 1997. "Geographic Concentration in U.S. Manufacturing Industries: A Dartboard Approach,” Journal of Political Economy, 105, 889-927.

[15] Glaeser, E. 1999. "Learning in cities," Journal of Urban Economics, 46, 254-277.

[16] Glaeser, E., H. Kallal, J. Scheinkman, and A. Shleifer. 1992. "Growth in cities," Journal of Political Economy, 100, 1126-1152.

[17] Glickman, N.J. and D.P. Woodward. 1987. Regional Patterns of Manufacturing Foreign Direct Investment in the United States. Report prepared for U.S. Department of Commerce, Economic Development Administration.

[18] Glickman, N.J. and D.P. Woodward. 1988. "The Location of Foreign Direct Investment in the United States: Patterns and Determinants," International Regional Science Review, 11, 137-154.

[19] Glickman, N.J. and D.P. Woodward. 1989. The New Competitors: How Foreign Investors are Changing the U.S. Economy. New York: Basic Books.

[20] Goldstein, G. and T. Gronberg. 1984. "Economies of Scope and Economies of Agglomeration,” Journal of Urban Economics, 16, 91-104.

[21] Guimarães P., O. Figueiredo, and D.P. Woodward. 2000. "Agglomeration and the Location of Foreign Direct Investment in Portugal," Journal of Urban Economics, 47, 115-35.

[22] Head, K.C., J.C. Ries, and D.L. Swenson. 1995. “Agglomeration Benefits and Location Choice: Evidence from Japanese Manufacturing Investments in the United States," Journal of International Economics, 38, 223-247.

[23] Head, K.C., J.C. Ries, and D.L. Swenson. 1999. "Attracting Foreign Manufacturing: Investment Promotion and Agglomeration," Regional Science and Urban Economics, 29, 197-218.

[24] Helsley, R.W. and W.C. Strange. 1990. "Agglomeration economies and matching in a system of cities," Regional Science and Urban Economics, 20, 189-212.

[25] Henderson, J.V. 1986. "Efficiency of resource usage and city size," Journal of Urban Economics, 19, 47-70.

[26] Henderson, J.V., A. Kuncoro, and M. Turner. 1995. "Industrial development in cities," Journal of Political Economy, 103, 1067-1085. 
[27] Jacobs, J. 1969. The Economy of Cities. New York: Random House.

[28] Jaffe, A., M. Trajtenberg, and R. Henderson. 1993. "Geographic Localization of Knowledge Spillovers as Evidenced by Patent Citations," Quarterly Journal of Economics, 108, 577-598.

[29] Krugman, P. 1991a. Geography and Trade. Cambridge, MA: MIT Press.

[30] Krugman, P. 1991b. "Increasing Returns and Economic Geography," Journal of Political Economy, 99, 483-499.

[31] Luger, M. and S. Shetty. 1985. "Determinants of Foreign Plant Start-ups in the United States: Lessons from Policymakers in the Southeast," Vanderbilt Journal of Transnational Law, 18, 223-245.

[32] Mariotti, S. and L. Piscitello. 1995. "Information Costs and Location of FDIs within the Host Country: Empirical Evidence from Italy,” Journal of International Business Studies, $26,815-841$.

[33] Marshall, A. 1898. Principles of Economics. London: Macmillan.

[34] McFadden, D. 1974. "Conditional Logit Analysis of Qualitative Choice Behavior," in P. Zarembka, ed., Frontiers in Econometrics. New York: New York Academic Press, 105142.

[35] Ondrich, J. and M. Wasylenko. 1993. Foreign Direct Investment in the United States. Kalamazoo, MI: Upjohn Institute.

[36] Porter, M. 1996. "Competitive Advantage, Agglomeration Economics, and Regional Policy," International Regional Science Review, 19, 85-91.

[37] Quigley, J. 1998. "Urban Diversity and Economic Growth," Journal of Economic Perspectives, 12, 127-138.

[38] Romanian Development Agency. 1996. Annual Report - 1996. Bucharest: RDA.

[39] Rhode, P.W. and K.S. Strumpf. 2003. “Assessing the Importance of Tiebout Sorting: Local Heterogeneity from 1850 to 1990," American Economic Review, 93, 1648-1677.

[40] Rivera-Batiz, F. 1988. "Increasing Returns, Monopolistic Competition, and Agglomeration Economies in Consumption and Production," Regional Science and Urban Economics 18, 125-153.

[41] Rosenthal, S.S. and W.C. Strange. 2001. “The Determinants of Agglomeration," Journal of Urban Economics, 50, 191-229. 
Research Papers in Environmental and Spatial Analysis No.105

[42] Sveikauskas, L. 1975. "The Productivity of Cities," Quarterly Journal of Economics, 89, 393-413.

[43] Train, K. 1985. Qualitative Choice Analysis: Theory, Econometrics, and an Application to Automobile Demand. Cambride, MA: MIT Press.

[44] Voicu, I. 2000. Determinants and Effects of Foreign Direct Investment in Romania. Ph.D. Dissertation, Rutgers University.

[45] Wheeler, D. and A. Mody. 1992. "International Investment Location Decisions: The Case of U.S. Firms,” Journal of International Economics, 33, 57-76.

[46] Woodward, D. 1992. "Locational Determinants of Japanese Manufacturing Start-Ups in the United States," Southern Economic Journal, 58, 261-273. 
Research Papers in Environmental and Spatial Analysis No.105

\section{Summary Statistics and Regression Tables}

\section{TABLE 1}

Distribution of Manufacturing Establishments with Foreign Participation by County, 1990-1997

\begin{tabular}{|c|c|c|}
\hline County Name & Number & Percent \\
\hline ALBA & 5 & 0.3 \\
\hline ARAD & 35 & 2.3 \\
\hline ARGES & 16 & 1.0 \\
\hline BACAU & 20 & 1.3 \\
\hline BIHOR & 56 & 3.6 \\
\hline BISTRITA-NASAUD & 7 & 0.5 \\
\hline BRASOV & 33 & 2.1 \\
\hline BRAILA & 6 & 0.4 \\
\hline CARAS-SEVERIN & 6 & 0.4 \\
\hline CLUJ & 45 & 2.9 \\
\hline CONSTANTA & 45 & 2.9 \\
\hline COVASNA & 15 & 1.0 \\
\hline DIMBOVITA & 8 & 0.5 \\
\hline DOLJ & 21 & 1.4 \\
\hline GALATI & 7 & 0.5 \\
\hline HARGHITA & 35 & 2.3 \\
\hline HUNEDOARA & 7 & 0.5 \\
\hline IALOMITA & 5 & 0.3 \\
\hline IASI & 20 & 1.3 \\
\hline MARAMURES & 10 & 0.7 \\
\hline MURES & 22 & 1.4 \\
\hline NEAMT & 7 & 0.5 \\
\hline PRAHOVA & 19 & 1.2 \\
\hline SATU MARE & 6 & 0.4 \\
\hline SIBIU & 33 & 2.1 \\
\hline SUCEAVA & 8 & 0.5 \\
\hline TIMIS & 82 & 5.3 \\
\hline VALCEA & 7 & 0.5 \\
\hline VRANCEA & 6 & 0.4 \\
\hline BUCHAREST & 942 & 61.2 \\
\hline GIURGIU & 6 & 0.4 \\
\hline TOTAL & 1540 & 100.0 \\
\hline
\end{tabular}

Notes: The statistics in this table include all manufacturing establishments with at least $\$ 10,000$ in foreign capital which are either 100 percent foreign-owned or have a physical person as a domestic partner. Source: Authors' calculations based on data from the Romanian Development Agency. 
Research Papers in Environmental and Spatial Analysis No.105

TABLE 2

Distribution of Manufacturing Establishments with Foreign Participation by Year of Establishment

\begin{tabular}{rrr}
\hline \hline Year & Number & Percent \\
\hline 1990 & 21 & 1.4 \\
1991 & 30 & 2.0 \\
1992 & 57 & 3.7 \\
1993 & 78 & 5.1 \\
1994 & 360 & 23.4 \\
1995 & 377 & 24.5 \\
1996 & 359 & 23.3 \\
1997 & 258 & 16.8 \\
\hline Total & 1540 & 100.0 \\
\hline
\end{tabular}

Notes: The statistics in this table include all manufacturing establishments with at least $\$ 10,000$ in foreign capital which are either 100 percent foreign-owned or have a physical person as domestic partner. Source: Authors' calculations based on data from the Romanian Development Agency.

TABLE 3

Distribution of Manufacturing Establishments with Foreign Participation by Industry, 1997

\begin{tabular}{lrr}
\hline \hline Industry & Number & Percent \\
\hline Metal products, machinery \& equipment & 73 & 4.7 \\
Electronics \& electric apparatus & 121 & 7.9 \\
Chemicals & 163 & 10.6 \\
Wood & 163 & 10.6 \\
Light industry ${ }^{\text {i) }}$ & 378 & 24.6 \\
Food & 616 & 40.0 \\
Publishing \& printing & 18 & 1.2 \\
Nonmetallic minerals & 8 & 0.5 \\
\hline Total & 1540 & 100.0 \\
\hline
\end{tabular}

Notes: The statistics in this table include all manufacturing plants with at least \$10,000 in foreign capital. ${ }^{\text {i) }}$ Includes textile, clothing, leather \& shoes. Source: Authors' calculations based on data from the Romanian Development Agency. 
Research Papers in Environmental and Spatial Analysis No.105

TABLE 4

Description of Explanatory Variables

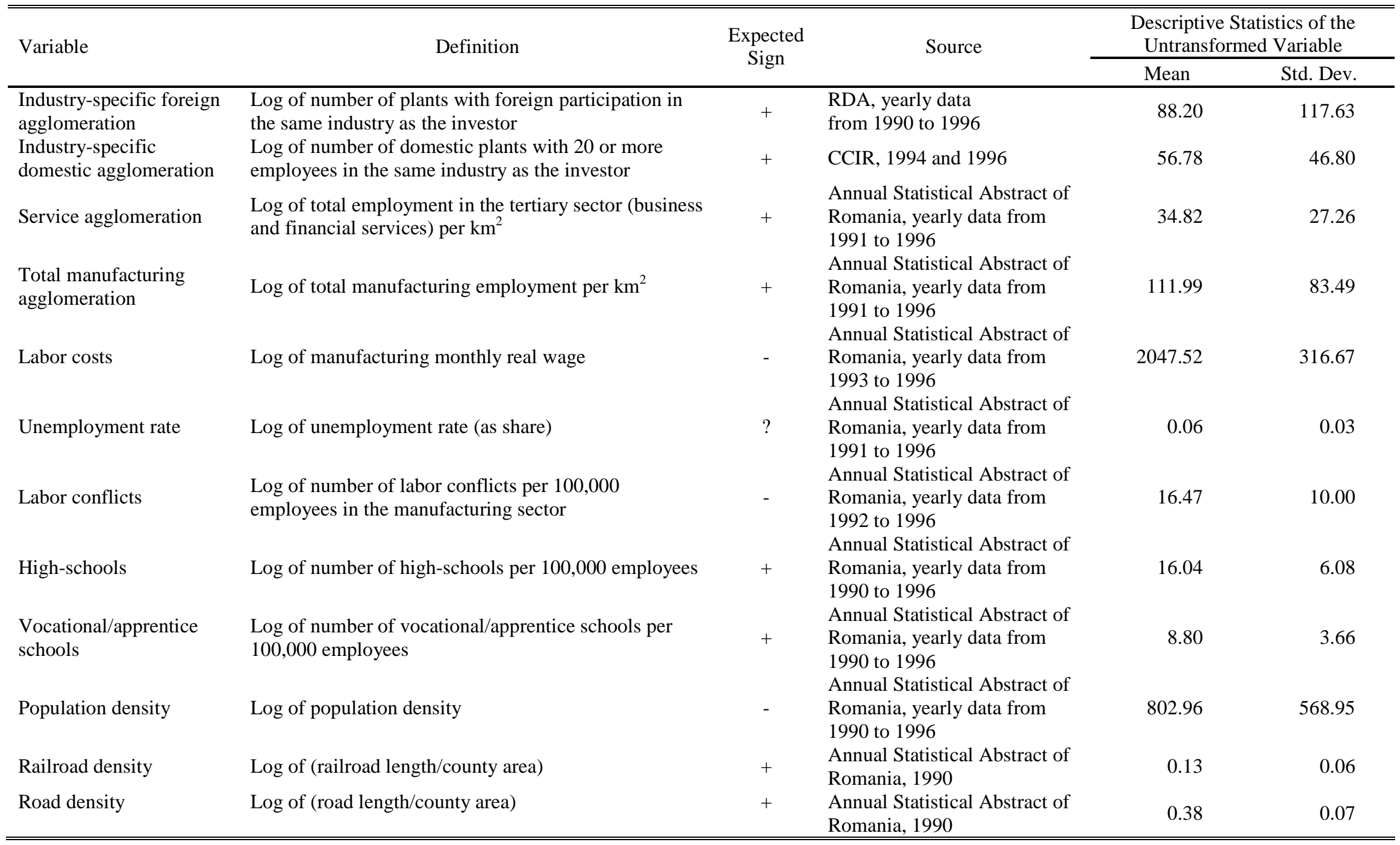


Research Papers in Environmental and Spatial Analysis No.105

Notes: As indicated in the Source column, for some variables, data was not available for the beginning of our study period. We imputed the missing values of all these variables, except labor costs (wage), with their values for the first available year of data. We imputed the missing labor cost values via extrapolation of the available years of data based on the average annual wage growth during these years. 
Research Papers in Environmental and Spatial Analysis No.105

TABLE 5

Conditional Logit Estimates, 1991-97

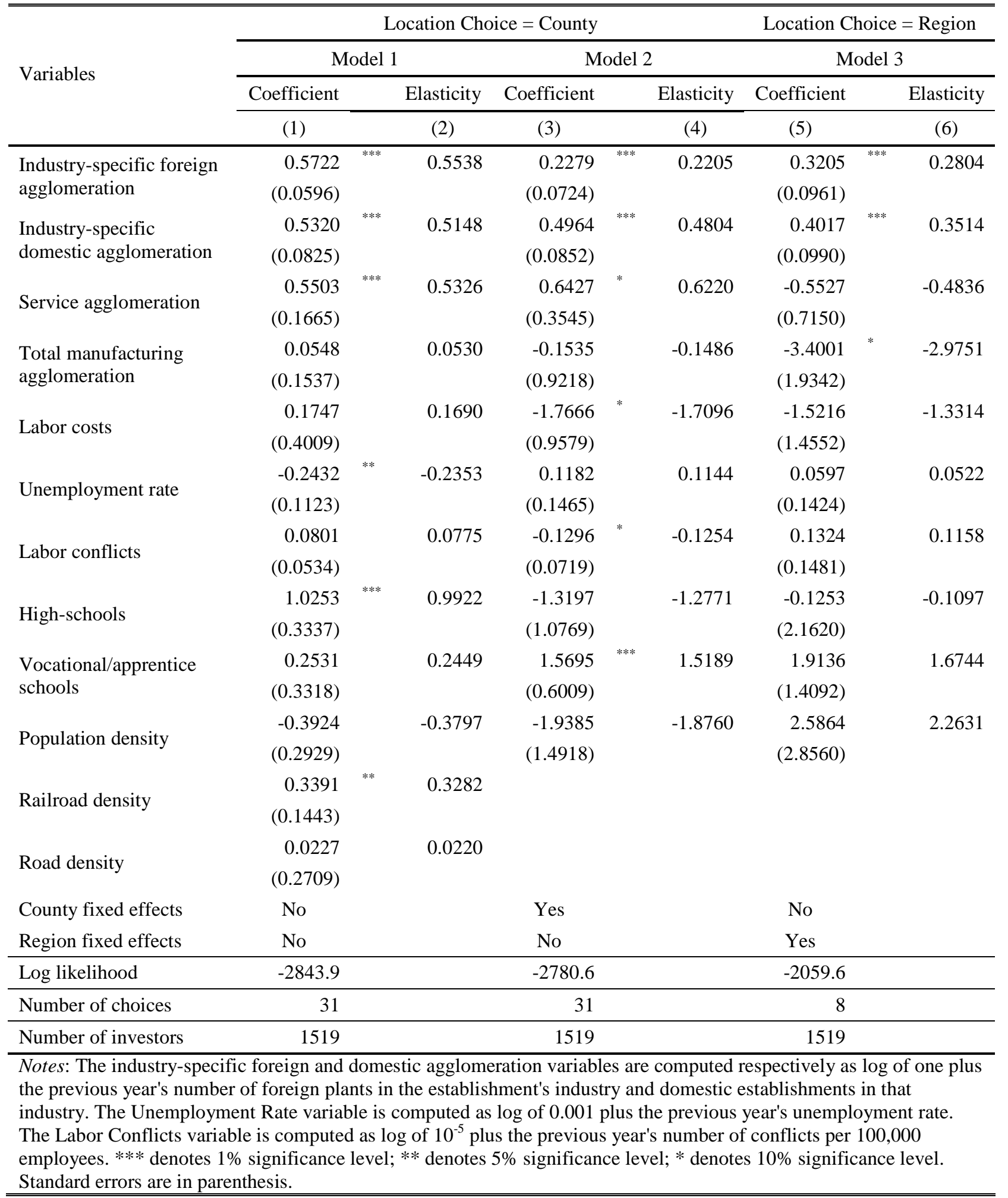

